\title{
The development of a professional development intervention for mathematical problem-solving pedagogy in a localised context
}

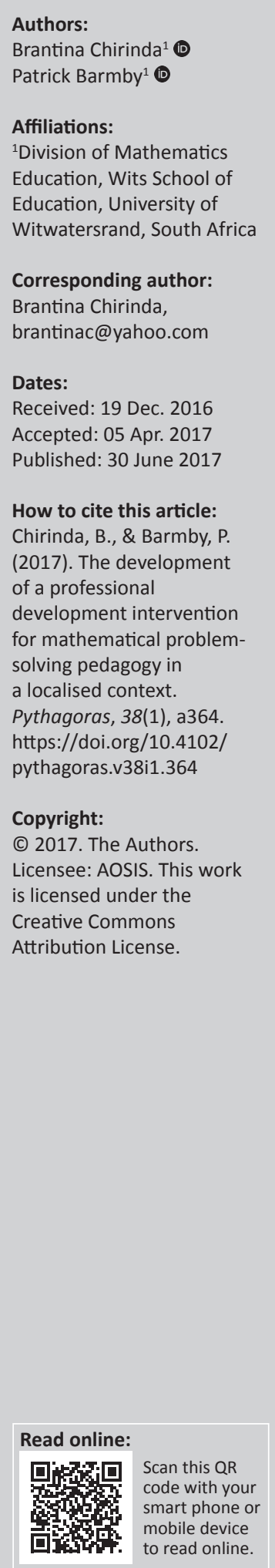

This article reports on the design and findings of the first iteration of a classroom-based design research project which endeavours to design a professional development intervention for teachers' mathematical problem-solving pedagogy. The major outcome of this study is the generation of design principles that can be used by other researchers developing a professional development (PD) intervention for mathematical problem-solving pedagogy. This study contributes to the mathematical problem-solving pedagogy and PD body of knowledge by working with teachers in an under-researched environment (an informal settlement in Gauteng, South Africa). In this iteration, two experienced Grade 9 mathematics teachers and their learners at a public secondary school in Gauteng, South Africa, participated in a 6-month intervention. Findings from the data are discussed in light of their implications for the next cycle and other PD studies.

\section{Introduction}

Mathematics is an essential requirement for entry into South African universities and other tertiary institutions and is a 'critical competency for the development of sorely-needed high-level skills' (Centre for Development and Enterprise, 2014, p. 1). However, South African learners' performance in mathematics on local and international tests of educational achievement has been a major cause for concern. Learner achievements in mathematics are still at an unacceptable level (Department of Basic Education [DBE], 2014). After the release of the Annual National Assessments (ANA) 2013 results, a diagnostic report was generated by the DBE showing that some of the numerous challenges learners experienced in certain mathematics topics were as a result of 'ineffective teaching methods' (DBE, 2014, p. 7). Feza-Piyose (2012) agrees with this finding and affirms that quality of instruction is one of the contributing factors to the poor performance of the majority of South African learners. A number of studies (Adler \& Ronda, 2014; Mji \& Makgato, 2006; Mullis, Martin, Foy \& Arora, 2012; Taylor \& Vinjevold, 1999) have also outlined numerous flaws in the teaching and learning of mathematics in South Africa.

Many curricula (DBE, 2011; Ministry of Education Singapore, 2013; National Council of Teachers of Mathematics, 2000) consider problem solving an essential aspect of mathematics teaching and learning. The Curriculum and Assessment Policy Statement (CAPS) states that problem solving and cognitive development should be fundamental to all mathematics teaching. However, this is not what a number of researchers have found in South African mathematics classrooms. Adler and Ronda (2014) observe that South African teachers tend to implement traditional approaches in the classroom. They start the learning day by revising the previous day's homework, demonstrating the new work with an example, and giving the learners some exercises to do. Taylor and Vinjevold (1999) found that some South African mathematics teachers spend a whole lesson doing problems that simply require the application of algorithms and hardly teach genuine problem solving. Mji and Makgato (2006) also perceive that outdated teaching practices have caused poor teaching standards in South Africa. In response to these identified problems, we propose to design a professional development (PD) intervention to support mathematics teachers in teaching problem solving. Traditionally, professional development is normally delivered in the form of workshops, college courses, seminars or conferences (Villegas-Reimers, 2003) but these approaches have been fiercely criticised for their ineffectiveness since they are not directly related to an individual teacher's practice (Hawley \& Valli, 1999). For this reason, we engaged the process of design-based research (DBR) to tailor a PD intervention that would be appropriate for teachers in a particular local context. We anticipated that DBR would permit us to refine and redesign our PD intervention based on multiple iterations in a naturalistic setting. The following were the research objectives of the larger project, from which the present study was taken: 
- Design an effective PD intervention for mathematical problem-solving pedagogy.

- Explore the learning of participant teachers and learners from participating in the PD intervention.

- Examine and evaluate the potential impact of the PD intervention.

- Generate design principles that can be used to develop a PD intervention on mathematical problem-solving pedagogy for Grade 9 teachers in a particular local context.

This article reports on the first iteration of the PD intervention on mathematical problem-solving pedagogy. We formulated and sought to answer the following research questions:

- What is the impact of the PD intervention on learners' learning processes?

- What is the impact of the PD intervention on teachers teaching of problem-solving?

- What factors facilitated learners' learning and teachers' development of pedagogy?

- What are the possible design principles required to generate a PD intervention on mathematical problemsolving pedagogy for Grade 9 teachers in a particular local context?

\section{Literature review}

\section{Problem solving}

Traditional methods of teaching mathematics, prevalent in the South African context (Adler \& Ronda, 2014), are very different from the teaching of problem solving that takes place while learners are 'grappling' with a problem (Murray, Olivier \& Human, 1998). Traditional methods of teaching give emphasis to the teaching of algorithms, while problem solving is the whole process of dealing with a problem (Wessels \& Kwari, 2003). Problem solving is a fundamental characteristic of the teaching and learning of mathematics. The National Council of Teachers of Mathematics (2000, p. 52) defines problem solving as 'engaging in a task for which the solution method is not known in advance'. Polya (1957) sees it as finding a path around a challenge or an obstacle and finding a solution to a problem that is not known. Over the years as teachers, we have experienced that when a teacher genuinely teaches mathematical problem solving, learners are placed in the active role of problem-solvers by being confronted with unfamiliar tasks that have no readily known procedure or algorithm (Murray et al., 1998). The teacher poses nonroutine mathematical problems to learners for solving and they are expected to justify and explain their solutions. During problem-solving, the previously attained experience is applied to an unfamiliar situation that contains major obstacles in order to find a solution to the problem and learners are required to think deeply about what solution strategy to implement. Dewey (1933), Polya (1957), Krulik and Rudnick (1980) and Barmby, Bolden and Thompson (2014) have identified steps in the problem-solving process. We chose Polya's steps to base our PD intervention on because they encapsulate the key aspects of mathematical problem-solving that comprises this study.
Polya (1957) proposed a four-phase problem-solving process, with identifiable strategies:

- Understanding the problem.

- Devising a plan or deciding on a strategy for attacking the problem.

- Carrying out the plan; that is learners follow through with the strategy selected, carefully taking each step along the away.

- Looking back at the problem, the answer and what one has done to get there.

During the intervention, we worked with teachers on how to use Polya's steps in their teaching. We discussed how teachers could work with learners on understanding given problems. Teachers were encouraged to ask learners questions like: Do you understand what the problem is looking for? Do you know all the words? Can you repeat the problem in your own words? We discussed with teachers how they could help learners to create a plan to solve a given problem. Teachers could ask learners questions like: What operation are you going to engage? A table? Do you need to draw a picture? Would you use an equation? Teachers were encouraged to assist learners during carrying out the plan that is, doing calculations. We discussed ways teachers could help learners to persist with a chosen plan and if a plan does not work to discard it and choose another. After getting a solution to the given problem teachers were persuaded to always facilitate learners to review their answers by reflecting and looking back at what worked and what did not.

\section{Effective professional development for teachers}

Our objective for the main study is to design an effective PD intervention that can be used to support mathematics teachers in the teaching of mathematical problem solving. Day (1999) defines PD as a process by which, either individually or with colleagues, teachers review, renew and broaden their commitment as change agents to the moral purposes of teaching, and by which they acquire and develop critically the knowledge, skills, planning and practice with children, young people and colleagues through each phase of their teaching lives. Wei, Darling-Hammond, Andree, Richardson and Orphanos (2009) see it as the processes and activities designed to improve teachers' knowledge, the practice of instruction, and the learning outcomes of learners. In turn, Quick, Holtzman and Chaney (2009) state that the main objective of PD is, through teachers, to increase learner achievement.

Effective PD should be based on constructivism (VillegasReimers, 2003); teachers should be treated as active learners who construct their own understanding (Putnam \& Borko, 1997). Gulamhussein (2013) concurs with this and stresses that during PD, teachers must be engaged through varied approaches so that they can participate actively in making sense of a new practice. Reflection is one approach teachers can be involved in. It is what a teacher does when they look back at the teaching and learning that has occurred and reconstruct the events, emotions, and experiences of the 
situation (Wilson, Shulman \& Richert, 1987). The capability by an individual teacher to reflect on their actions is a crucial aspect of PD. Schunk (2012) advocates that this process of reflection results in teachers incessantly changing and improving their views on effective teaching and this, in turn, results in their PD.

Effective PD must be perceived as a process that takes place within a particular context (Villegas-Reimers, 2003) and must be situated in classroom practice (Putnam \& Borko, 1997). PD should focus on changing teaching practices positively while valuing particular teachers' personal, social and professional needs (Loucks-Horsley \& Stiegelbauer, 1991). This is echoed by Villegas-Reimers who accentuates that PD is not similar in different settings, that is, what works for teachers in a certain area may not work for other teachers in a different area. Consequently, we adopted classroom-based design research in order to design a PD intervention that would work specifically for teachers in our context of study.

\section{Theoretical perspective}

Social constructivism informed this study. The social constructivist perspective to learning mainly originates from the work of Vygotsky (1986). It emphasises that culture and social contexts are important in understanding what occurs in a society and acquiring knowledge based on this understanding. Learning is considered to be situationspecific and a context-bound activity (Woolfolk, 2007), in line with the view of PD given above. This study took place in an under-resourced African context, where the teachers were working with large classes, with learners with English as a second language. The teachers had a wealth of experience of teaching mathematics based on their own cultural and social experiences. Therefore, we began with the teachers' experiences and how they were teaching problem solving, and we employed the DBR approach to develop the PD intervention within this context.

Social constructivism emphasises that knowledge is mutually built and constructed (Vygotsky, 1986). By interacting with others, teachers or students share their views and automatically construct a common understanding connected to the concept under discussion. The notion of social constructivism is an appropriate perspective for this study because this study was structured in such a way that teacher social participation, reflections, and experiences evoked their learning of the teaching of problem solving in their particular contexts. Participant teachers were required to share their experiences with other participant teachers and collaboratively learned from each other. In the PD workshops participant teachers spent considerable time interacting, investigating, explaining and discussing mathematical problem-solving pedagogy ideas. During lesson delivery we encouraged teachers to act as facilitators of learning and allow learners to actively construct knowledge individually from their prior experiences or collaboratively with their peers through discussions.

\section{Conceptual framework}

The conceptual framework we drew on is that of problemcentred learning. The problem-centred teaching and learning approach is a learner-centred educational method that uses problem solving as the starting point for learning and as a 'vehicle for learning' (Murray et al., 1998, p. 171). It means both the curriculum and instruction should begin with problems, dilemmas and questions for learners (Wessels \& Kwari, 2003) and the subject should be allowed to be 'problematic' (Hiebert et al., 1997, p. 12). Learning occurs when learners actively grapple with problems for which they have no routine methods available (Murray et al., 1998) and involves the learning of mathematics through real contexts, problem situations and models (Van de Walle, Karp \& BayWilliams, 2013). For this study, teachers were encouraged to use problem-solving as a technique for helping learners to learn mathematics. Learners constructed new mathematical knowledge and problem-solving skills after actively grappling with non-routine problems and reflecting on their problemsolving experiences and solution strategies.

\section{Methodology Research design}

Design-based research (Kelly, 2003), also known as educational design research (McKenney \& Reeves, 2012), design experiments (Collins, 1992) and development research (Van den Akker, 1999), is a relatively new research approach in the field of educational inquiry. However, there is increasing recognition internationally of DBR as part of evidence-based educational research (Design-Based Research Collective, 2003). The Design-Based Research Collective further states that educational researchers and practitioners concur that educational research is frequently unconnected to the problems and issues of everyday practice. However, DBR aims to solve real-world problems by designing, enacting and sustaining interventions (Van den Akker, Gravemeijer, McKenny \& Nieveen, 2006). For this study, DBR allowed us to be connected to the research problem in a specific setting.

A number of researchers have attempted to give a definition of DBR and there is a discussion underway of what constitutes DBR (Van den Akker et al., 2006). Wang and Hannafin (2005)'s definition encapsulates the key aspects of DBR that comprise this study. Wang and Hannafin (2005) define DBR as

a systematic but flexible methodology aimed to improve educational practices through iterative analysis, design, development, and implementation, based on collaboration among researchers and practitioners in real-world settings, and leading to contextually-sensitive design principles and theories. (p. 6)

This definition implies that in DBR, researchers work as a team with practitioners to provide solutions to practical challenges that face a particular educational context. There is general agreement that DBR should generate valuable educational interventions and useful theory (Van den Akker et al., 2006). DBR uses the terminology of 'intervention' to refer to the object, output, activity or process that is designed 
as a possible solution to the identified problem. Intervention is defined by McKenney and Reeves (2012) as a comprehensive term used to encompass the various kinds of solutions that are designed. These various solutions can be educational products, processes, policies or programmes. This study developed a PD intervention for mathematical problemsolving pedagogy for Grade 9 mathematics teachers in a certain district in Gauteng.

\section{Context and the design process}

The larger classroom-based design project focuses on designing a PD intervention on mathematical problemsolving pedagogy that can be further modified and used with schools in challenging contexts in South Africa. The larger project has three iterative cycles. In March 2016 we conducted a baseline investigation with 31 teachers at 20 schools in the district of interest. The baseline investigation examined how Grade 9 mathematics teachers in this district were using problem-solving in their teaching of mathematics. We 'purposefully' selected three schools A, B and C, out of the initial 20 schools. These schools were chosen because they could be conveniently accessed by the researchers and the Grade 9 mathematics teachers reported that they were using traditional methods of teaching. This article reports on the first iteration of the larger project, which is the phase of the intervention in which we worked with two teachers in school A. Teachers in school B and school C were investigated in cycle $B$ and cycle $C$ respectively. The goal was to work with at least two Grade 9 mathematics teachers from each school; however, this depended on the number of teachers teaching Grade 9 mathematics at a particular school.

\section{Design of the professional development intervention}

The PD intervention is designed to take place within a period of 6 months. The goals we set for the PD intervention were to improve learners' performance in mathematics and support teachers' mathematical problem-solving pedagogy. We also aimed to explain and agree with participant teachers what mathematical problem-solving pedagogy is and what it is not. PD took place during the process of classroom instruction in order to link with classroom teaching (Barber \& Mourshed, 2007). We conducted three PD workshops with teachers on the last Wednesday of each month. The workshops were from 12:00 to 15:00, $3 \mathrm{~h}$ per workshop. This resulted in a total of $9 \mathrm{~h}$ of training for participant teachers. We carried out the training at a community centre in this district. We received funding from a non-governmental organisation and gave participant teachers a stipend to arrange work for their classes before leaving the school for the programme and to cover their lunch and transport costs. These workshops were different from the traditional 'one-shot' workshops in that the teachers attended the workshop three times, collaboratively learned from each other during the intervention, were actively engaged in meaningful discussion, planning and practice (Loucks-Horsley, Hewson, Love \& Stiles, 1998) and we observed and supported the teachers during the implementation. We selected PD activities that offered teachers the opportunity to become actively engaged in the meaningful analysis of teaching and learning.

In the first workshop, we initially presented the workshop's contents to the participant teachers who then watched two short videos on mathematical problem-solving pedagogy in action. The baseline investigation we conducted before implementing this intervention unearthed that participant teachers believed that teaching mathematical problem solving was about explaining to learners each and every concept, step-by-step, breaking down the topic, working out examples on the chalkboard and giving learners practice exercises to work on. Therefore, these videos were to show the teaching of mathematical problem solving in action. We discussed the videos, focusing on what genuine mathematical problem-solving pedagogy entails and how to apply Polya's four steps of problem solving as a teaching process. Teachers expounded on ways of introducing or posing the problems in such a way that learners understand the given problems. Teachers collaboratively solved at least two 'rich' and openended mathematical tasks relating to the work they were teaching, and with our guidance discussed how to teach problem solving as a process.

After attending the first PD workshop, teachers were encouraged to go and implement the new ideas in their lessons for a month. During this implementation stage, we observed, supported and guided the participant teachers as was necessary and audiotaped the lessons. It is imperative that teachers are supported during the implementation stage to address the specific challenges of changing classroom practice (Gulamhussein, 2013), receive feedback and be given the opportunity to reflect critically (Bell \& Gilbert, 1994).

We encouraged teachers to reflect-in-action and reflect-onaction (Schön, 1983) during the implementation. Schön defines reflection-in-action as the teachers' aptitude to reflect throughout the lesson rather than after the lesson. Reflectionon-action encompasses teachers thinking about, commenting on, analysing and evaluating the lesson after it has been completed. Throughout the implementation phase participant teachers were encouraged to continuously reflect on their experiences as learners of the PD programme and on their classroom practices.

After the first implementation, we conducted the second workshop where the aim was for teachers to further collaboratively reflect on their teaching experiences and to review the audio tapes of the observed lessons. We selected crucial and relevant audio recordings that foregrounded participant teachers' use of problem solving in their teaching. Participant teachers analysed how they had taught mathematical problem-solving and they watched two further videos showing mathematical problem-solving pedagogy in action. Once again teachers collaboratively solved mathematical tasks relating to what they were teaching and planned on how to teach similar tasks to their learners. After workshop 2 the teachers implemented new ideas for a month while being observed, supported, 
audiotaped and interviewed by the researchers. We also encouraged the teachers to continuously reflect on their experiences and classroom practices. The third workshop and the implementation process were similar to the second stage.

\section{Data sources}

Teacher data were collected through classroom observations and semi-structured reflective interviews. In order to get first-hand experiences when teachers implemented the problem-solving pedagogy, we observed them delivering lessons and recorded information on the spot as it occurred on the observation comment card. The observation comment card (see Appendix 1) is a valid tool for the collection of data from teachers during the teaching of mathematical problem solving because it incorporates Polya's problem-solving processes. Teachers need to assume certain roles in each problem-solving stage and these are all covered in the teacher observation comment card. Classroom observations which were audiotaped were conducted before, during and after the PD intervention. We were at the school every Wednesday and observed Mrs X's and Mrs Y's lessons consecutively. In total, we had 13 observations with each teacher. Audio recordings permitted us to record the observed lessons as they transpired and gave us the chance to re-experience the lessons at a later convenient time.

Semi-structured reflective interviews with the participant teachers were conducted with each teacher once a month and were conducted in their classrooms since it was during their free periods. In total, we had five interviews with each teacher. Opie (2004) points out that interviews are extremely important as a data collection tool because they draw out data that participants may not display during observations.

In terms of assessing the possible impact of the PD intervention on participant learners, we gave them mathematics attainment tests pre- and post-intervention and a self-reporting mathematical problem-solving skills inventory (MPSSI) at the beginning and at the end of the intervention. We used teachers' pre- and post-intervention mathematics attainment tests that covered the topics that the learners were doing (geometry and data handling). The questions on the pre-intervention test were different but similar in all respects to those of the post-intervention test. Both tests had 15 questions and the marks were converted to a percentage. The attainment tests were useful in evaluating learners' ability to use mathematical problem-solving skills because they required learners to supply the answers thereby avoiding guesses.

The MPSSI (see Appendix 2) was developed by the researchers based on the mathematical problem-solving skills found in the literature (Hiebert \& Wearne, 1993; Kadel, 1992; Polya, 1957; Van de Walle et al., 2013) and it was used to establish if Grade 9 learners perceived themselves as having developed mathematical problem-solving skills after the intervention. Learners were required to evaluate their own competencies on each item on a five-point scale. We chose the MPSSI as a data collection tool because it provided learner data that supplemented the data from the pre- and post-intervention attainment tests and this allowed learners to fully contribute to the data collection process.

\section{Data analysis}

Our raw data included recorded notes on the observation comment card, audio tapes from the classroom observations and semi-structured interviews, test marks and responses from the MPSSI. Audio tapes from the classroom observations and semi-structured interviews were transcribed verbatim into written notes in order to be able to identify common patterns and experiences. We employed inductive data analysis to analyse the teacher qualitative data from the observations and the semi-structured interviews (Hatch, 2002). According to McMillan and Schumacher (2014), qualitative data analysis is an inductive process of organising data into categories and identifying patterns among the categories. This concurs with Creswell and Plano Clark (2011, p. 208) who affirm that qualitative data analysis involves 'coding the data, dividing the text into small units, assigning a label to each unit and then grouping the codes into themes'. Inductive data analysis permits the researcher to identify themes that emerge from the data (Hatch, 2002) and not from predetermined categories. The statistical software package SPSS was used to analyse the learner quantitative data from the pre- and post-intervention mathematics tests and the MPSSI.

\section{Ethical considerations}

This was an ethical study; therefore, the researchers took precaution to protect the autonomy and anonymity of participant teachers. Letters of permission were sent to and subsequently returned from the Gauteng Department of Education, Johannesburg North District of Education, selected school principals, participant mathematics teachers, learners and their parents or guardians. Participants were given detailed information about the proposed study and were clearly informed of the confidential nature of the research. We ensured that participation was voluntary; confidentiality was prioritised, and participants could freely withdraw from the study at any time without incurring any negative consequences, although none did. All responses were anonymised before analysis; neither the participant schools nor the teachers' names were identified in any report of the results of the study.

\section{Findings \\ Learners}

The MPSSI results exhibited substantial gains in percentages for each question (see Table 1). Table 1 shows the pre- and post-intervention percentages for each of the 13 items on the MPSSI, showing the percentage of learners that agreed or strongly agreed with each item. For example, on Question 1 'I always read the problem carefully to understand it' $-34 \%$ 
TABLE 1: Results from the mathematical problem-solving skills inventory.

\begin{tabular}{|c|c|c|c|c|c|c|c|c|c|c|c|c|c|}
\hline Test & Q1 & Q2 & Q3 & Q4 & Q5 & Q6 & Q7 & Q8 & Q9 & Q10 & Q11 & Q12 & Q13 \\
\hline Pre intervention & 34 & 10 & 2 & 10 & 18 & 32 & 18 & 14 & 26 & 14 & 28 & 22 & 22 \\
\hline Post intervention & 86 & 54 & 42 & 48 & 76 & 72 & 54 & 70 & 80 & 72 & 66 & 86 & 84 \\
\hline
\end{tabular}

$\mathrm{Q}$, question.

of the learners agreed or strongly agreed with this statement pre intervention, and this figure rose to $86 \%$ post intervention. We concluded that the learners perceived an increase in their mathematical problem-solving skills after participating in the intervention.

There was an increase in the learner attainment test scores and this indicated that there were gains in learner attainment. Table 2 shows the average percentages on the pre- and post-intervention attainment tests with the standard deviation of each set of marks. We concluded that the PD intervention had a positive impact on learners' performance.

\section{Teachers}

\section{Findings from teacher observations}

The findings from the teacher classroom observations are presented under the three themes: understanding the problem, collaborative learning and encouraging metacognition.

Understanding the problem: The observations we conducted before implementation of the intervention unearthed that the participant teachers relied solely on the DBE prescribed textbook. They introduced the topic by demonstrating the examples in the textbook on the board and there was no clarification of the task at hand. The teachers did not verify if learners understood what was being demonstrated on the board. After demonstrating examples on the board, teachers would give learners homework from the prescribed textbook. After the first workshop teachers began to gradually implement what they had learned from the mathematical problem-solving pedagogy training. Teachers began to encourage learners to read and understand the given problem before attempting it. Teachers required learners to paraphrase the problem at hand in their own words as a way of demonstrating that they indeed understood. English language, the language of instruction, proved to be an obstruction to learners' understanding. The researchers encouraged the teachers to code-switch as necessary. As the intervention progressed, teachers assisted learners to understand the given problems by discussing any unfamiliar terms in the problems and requiring them to underline key words in a given problem. In one instance during a data handling lesson, Mrs Y posed a problem on the total number of fatal accidents in each province on South African roads. In this problem learners were required to find measures of central tendency and dispersion. Mrs Y required the learners to firstly underline the key words in the problem and discuss in pairs the unfamiliar terms, that is, 'measures of central tendency' and 'measures of dispersion'. Learners were required to verbalise and restate the given problems in
TABLE 2: Results from the pre- and post-intervention attainment tests.

\begin{tabular}{lcc}
\hline Test & Average percentage on test & Standard deviation \\
\hline Pre-intervention test & 19.2 & 16.2 \\
Post-intervention test & 37.8 & 17.5 \\
\hline
\end{tabular}

their own words to prove that they really understood the posed problem. In one lesson, we observed that Mrs X encouraged learners to verbalise their thinking processes during an investigation to establish the minimum conditions for congruent triangles.

Collaborative learning: As the intervention progressed, teachers arranged learners in pairs or groups of three or four for discussions. Learners were given the opportunity to brainstorm ideas and solution strategies, draw sketches or diagrams, look for patterns and generate solutions collaboratively. If learners' chosen strategies failed, teachers encouraged them to try another one. We observed that Mrs X put her learners into groups of three or four when they were investigating how doubling any or all of the dimensions of right prisms and cylinders affects their volume.

Encouraging metacognition: Metacognition is the conscious monitoring of one's own thinking and self-regulation of learning (Van de Walle et al., 2013). As the intervention progressed, teachers required that learners look back and reflect after getting solutions to check if the way they had solved the given problems was the best way, to clarify if there were other solutions other than what they had found and if their solutions were reasonable.

\section{Findings from the teacher semi-structured interviews}

The findings from the teacher semi-structured interviews are presented under the four themes that emerged from the interview data. The four themes are: changes in perceptions about mathematical problem-solving pedagogy, appreciation of collaborative learning, increased awareness of learners' needs and PD activities that had a positive impact on teachers' professional development.

Changes in perceptions about mathematical problemsolving pedagogy: Initially, teachers viewed the teaching of problem-solving as a step-by-step explanation, doing examples on the board and giving learners practice exercises. When we introduced mathematical problemsolving pedagogy, teachers perceived it as time-consuming and asserted that they had a lot of prescribed teaching material to cover. However, as the intervention progressed they began to understand and appreciate the teaching of mathematical problem solving as a process as illustrated by this quote from Mrs Y: 
Initially, I was confused and showed learners how to work a problem using drilling methods but now I know how to teach mathematical problem solving as a process. (Mrs Y, female, teacher)

Appreciation of collaborative learning: Both teachers valued collaborative learning as made explicit by Mrs X:

Working with my colleague during the workshops and teaching was superb because we could support each other and we shared ideas and obstacles. Collaboration made my learning effortless. I liked it. I became a better teacher by learning from my colleague. (Mrs X, female, teacher)

As the intervention progressed, participant teachers began to implement collaboration in their own teaching. Learners were required to work in pairs or in groups and this kept them on-task. Teachers were no longer the only source of knowledge and this helped with classroom management as learners had a responsibility of completing tasks in pairs or groups, as was highlighted by Mrs $\mathrm{Y}$ in one of the interviews:

As I arranged learners to work in pairs, they were no longer moving in and out of the classroom. Pairing them helped me with discipline and class control. (Mrs Y, female, teacher)

Increased awareness of learners' needs: The two participant teachers revealed that they had become more aware that they had to clarify the task at hand and make sure the learners understood before solving the given problem. This is illustrated by these quotes from Mrs Y:

This professional development intervention opened my eyes. I used to assume that learners understood the given questions but now I check if they really understand. If they don't we read the problem together, paraphrase the questions and I sometimes require learners to verbally tell me what the question would be asking for. (Mrs Y, female, teacher)

If my learners do not understand a given problem, I now re-read the problem for them or use their mother tongue to explain. This is to make sure that they understand the given problem. (Mrs Y, female, teacher)

Professional development activities that had a positive impact on teachers' professional development: Videos on mathematical problem-solving pedagogy that were shown during workshops were very positive for teachers, as articulated by Mrs Y:

To be able to see mathematical problem-solving teaching in action was intriguing. I saw where I was getting it wrong. It helped me to realise areas that needed improvement in my own teaching. (Mrs Y, female, teacher)

In addition, the teachers appreciated that we, the researchers who delivered the PD intervention were respectful to them and acknowledged their experiences, as expressed by Mrs X:

You treated me like an adult during the intervention. I have been to other workshops where I was treated like a child who knows nothing. You showed me respect. You were aware that I have fully trained to be a teacher and that I teach large classes. (Mrs X, female, teacher)
Finally, the teachers valued solving problems and simulating how to teach problem-solving during the workshops, as explained by Mrs Y:

To practically learn how to teach mathematical problem-solving during the workshops was helpful for me because it built my confidence before implementing the new ideas in the classroom. (Mrs Y, female, teacher)

\section{Discussion of findings, conclusions, and implications Factors that influenced change in learners}

The pre- and post-intervention tests and pre- and postintervention MPSSI demonstrated that the PD intervention had a positive impact on learners' performance. This finding resonates with Barber and Mourshed's (2007) results from their research of 25 national school systems: that there is a positive correlation between teachers' PD and learners' achievement. Classroom observations confirmed that teachers were working in a different way with learners and emphasising problem-solving approaches. Teachers were encouraging collaborative learning among learners. When learners grappled with the problems in pairs or groups, it allowed for richer and more worthwhile whole class discussion. After solving problems, teachers encouraged learners to look back on the answer and the solution process or method, and looking at the problem itself. This is the final and important step of mathematical problem solving. When learners were required to look back and justify their solutions, they were able to come up with solutions in many ways, were able to correct themselves and could easily discern if their solutions were appropriate.

Despite the apparent success of encouraging problem-solving approaches, we found that English was a major obstacle to learners' grasping of the given problems. The finding on language as an obstacle to learning in South African mathematics classrooms is in agreement with what a number of researchers have disclosed in the past (Adler, 2001; Setati \& Barwell, 2006; Webb \& Webb, 2008).

\section{Factors that influenced change in teachers' pedagogy}

The pre-intervention observations revealed that the lessons were teacher-led and teachers implemented traditional methods of teaching. This finding aligns with what other researchers have exposed (Adler \& Ronda, 2014; Chisholm et al., 2000; Taylor \& Vinjevold, 1999). Chisholm et al. (2000) lament that South African classrooms have remained teachercentred. However, as the intervention progressed we noticed that the teachers became more facilitators rather than teachers, giving learners the opportunity to grapple with the given problems. There was more group work and discussion among learners, and learners began to work with and listen to each other. All these aspects that were being exhibited in the lessons after we implemented the intervention are highlighted as important in problem-based learning (Murray et al., 1998; Van de Walle et al., 2013; Wessels \& Kwari, 2003). 
Teachers became more focused on working with learners to understand the given problems. Understanding is the first important step in the teaching of mathematical problem solving.

In situations where learners did not understand the given problems because of the language, teachers code-switched. This study fills a gap in the literature on professional development and problem-based learning as it unearthed that language and code-switching are important aspects to be considered when implementing a PD intervention in a multilingual context. We recommend that a PD programme should include a segment that supports teachers on how to appropriately conduct code-switching and to support learners with their language.

Initially, teachers were reluctant to participate in the intervention and implement the mathematical problemsolving pedagogy. They indicated that they were worried that they would fail to cover the CAPS syllabus within the prescribed time. This finding aligns with what Slattery (2013) states: that the syllabus and task completion places pressure on teachers. However, as the intervention progressed teachers became comfortable with mathematical problem-solving pedagogy and started implementing the new ideas.

We observed the participant teachers for a month before implementing the intervention and this created trust between us and the teachers, which resulted in teachers working comfortably with us. Teachers appreciated that we respected them and acknowledged their experiences. It was important that we were responsive to respecting the participant teachers because respect is a key aspect in an African culture. When implementing the PD we took into consideration the lack of resources in our context. These are important aspects to add to the PD literature: that respect is an important aspect of the African culture and should be considered when supporting African teachers in a PD programme. We recommend creating a positive relationship with teachers before implementing a PD intervention and building on teachers' experiences when training them.

Collaborative learning was beneficial to both participant teachers and learners. This outcome concurs with Cordingley, Bell, Thomason and Firth's (2005) finding from systematically reviewing 17 studies of collaborative or sustained continuous PD in diverse contexts. They discovered that when teachers engage in collaborative PD, there are vast improvements in learners' learning and behaviour, and in teachers' practices.

The semi-structured reflective interviews with participant teachers were imperative to the research process. As teachers looked back on classroom events during the interviews and made critical judgments about them, they modified their teaching behaviour and this resulted in them constructing knowledge about themselves, their teaching practices and their learners (Schunk, 2012). As participant teachers knowingly and systematically reflected on their teaching experiences (Farrell, 2007), we realised that they were consciously able to improve their own teaching. This procedure by teachers thinking about what they were doing and why they were doing it turned their experiences into meaningful learning. In this case, learning by teachers did not just happen but was derived from them constructing sense from their experiences and particular contexts.

Following up on teachers in the classrooms to check if they were correctly implementing the mathematical problemsolving pedagogy was advantageous as we were able to support teachers as necessary. This is different from the traditional 'one-shot' workshops and we recommend that PD practitioners should support the teachers in the classroom during the implementation stage.

\section{Design principles}

Design principles are one of the major outputs of DBR and McKenney and Reeves (2012) term them theoretical insights into a phenomenon in question, which recommend how to address specific issues in a range of settings. While we acknowledge that we have gone through only one cycle of the DBR, the study generated a number of design principles relating to the designing of a PD intervention for mathematical problem-solving pedagogy. These principles will inform the next cycle of the study and are imperative to mathematics education and PD practitioners who are in the process of designing professional development interventions. The design principles include:

- A baseline investigation must be conducted to establish teachers' perceptions and practices on the teaching of mathematical problem solving before implementing the PD intervention.

- Facilitators of PD must create a positive relationship with participant teachers before implementing the intervention.

- PD should be built from teachers' experiences and current knowledge of mathematical problem solving.

- Respecting participants is important in an African context when implementing the PD intervention.

- Facilitators of PD must observe teachers practically implementing the mathematical problem-solving pedagogy and support them as necessary.

- PD should be organised around collaborative problem solving.

- PD should support teachers on how to implement mathematical problem-solving pedagogy in a multilingual context.

\section{Implications of the findings for the next cycle}

One of the most significant outcomes from this cycle is that language stands so much in the way of learners' learning of mathematics. Polya's (1957) first step in mathematical problem solving is understanding the problem, and if learners struggle with language, it means that they do not even understand the given problems. Language and the problem-solving process cannot be separated. Therefore, in the next cycle, we will do a lot more with teachers on how we 
can support learners' difficulties with problem solving, English language and code-switching. In this cycle we used teachers' own tests to act as our pre- and post-intervention tests but in the next cycles we are going to design our own tests so that we can easily check on the reliability of these tests. In the next cycle we will also introduce learner task-based interviews to help us explain why learners were doing well in the post-intervention test and why they were giving better responses in the post-intervention MPSSI. We anticipate that the learner task-based interviews will explain if learners' improvements are real and if they would be doing problem solving differently from the way they would be doing it pre-intervention. In the next cycle participant teachers will also be observed delivering lessons by other participant teachers and given feedback. This development emerged from the usefulness of teachers observing practice (in the first cycle from videos) and the usefulness of working on and reflecting collaboratively on lessons.

\section{Conclusion}

The findings of the study may prompt other researchers to develop PD interventions in local contexts. The study, having been done at one school, means that the transferability of the findings to larger contexts can be challenging. However, DBR does not make generalisability claims as the effectiveness of a design is no guarantee of its effectiveness in other settings' (Collins, Joseph \& Bielaczyc, 2004, p. 18). However, we believe that the above design principles can be used by other researchers as starting points for developing PD interventions for mathematical problem-solving pedagogy for localised contexts.

\section{Acknowledgements}

We acknowledge the funding received from the National Research Fund (NRF) and the support we got from the school principal, Mathematics head of department and the two participant teachers from school A.

\section{Competing interests}

The authors declare that they have no financial or personal relationships that may have inappropriately influenced them in writing this article.

\section{Authors' contributions}

B.C. is the lead author and was also involved in the coding and analysis of the data. P.B. was involved in the coding and analysis of the data and contributed to the writing of the article.

\section{References}

Adler, J. (2001). Teaching mathematics in multilingual classrooms. Dordrecht: Kluwe Academic Publishers.

Adler, J., \& Ronda, E. (2014). An analytic framework for describing teachers mathematics discourse in instruction. In C. Nicol, P. Liljedahl, S. Oesterle, \& D. Allan (Eds.), Proceedings of the Joint Meeting of PME 38 and PME-NA 36(2) (pp. 9-16). Vancouver: PME.

Barber, M., \& Mourshed, M. (2007). How the world's best performing schools come out on top. London: McKinsey \& Company.
Barmby, P., Bolden, D., \& Thompson, L. (2014). Understanding and enriching problem solving in primary mathematics (critical teaching). Northwich: Critical Publishing.

Bell, B., \& Gilbert, J. (1994). Teacher development as professional, personal, and social development. Teaching and Teacher Education, 10(5), 483-497. https://doi. org/10.1016/0742-051X(94)90002-7

Centre for Development and Enterprise. (2014). What does research tell us about teachers, teaching and learner performance in mathematics? Johannesburg: Centre for Development and Enterprise. Available from http://www.cde.org.za/ wp-content/uploads $/ 2014 / 10 /$ Teachers $\% 20$ teaching $\% 20$ and $\% 20$ learner $\% 20$ performance $\% 20$ in $\% 20$ mathematics.pdf

Chisholm, L., Volmink, J., Ndhlovu, T., Potenza, E., Mohomed, H., Muller, J., et al. (2000). A South African curriculum for the twenty first century: Report of the Review Committee on Curriculum 2005. Pretoria: DOE.

Collins, A.M. (1992). Towards a design science of education. In E. Scanlon, \& T. O'Shea (Eds.), New directions in educational technology (pp. 15-22). Berlin Springer. https://doi.org/10.1007/978-3-642-77750-9_2

Collins, A., Joseph, D., \& Bielaczyc, K. (2004). Design research: Theoretical and methodological issues. The Journal of the Learning Sciences, 13(1), 15-42. https:// doi.org/10.1207/s15327809jls1301_2

Cordingley, P., Bell, M., Thomason, S., \& Firth, A. (2005). The impact of collaborative continuing professional development (CPD) on classroom teaching and learning. Review: How do collaborative and sustained CPD and sustained but not Review: How do collaborative and sustained CPD and sustained but not
collaborative CPD affect teaching and learning? London: EPPI-Centre, Social collaborative CPD affect teaching and learning? London: EPPI-Centre, Social
Science Research Unit, Institute of Education, University of London. Available from http://eppi.ioe.ac.uk/cms/Default.aspx?tabid=393

Creswell, J.W., \& Plano Clark, V.L. (2011). Designing and conducting mixed methods research. Thousand Oaks, CA: Sage.

Day, C. (1999). Developing teachers: The challenges of lifelong learning. London: Falmer.

Department of Basic Education. (2011). Curriculum and Assessment Policy Statement Mathematics Grades 7-9. Pretoria: DBE.

Department of Basic Education. (2014). Annual National Assessments: 2014 diagnostic report. Pretoria: DBE.

Design-Based Research Collective. (2003). Design-based research: An emerging paradigm for educational inquiry. Educational Researcher, 32(1), 5-8. https://doi. org/10.3102/0013189X032001005

Dewey, J. (1933). How we think. Boston, MA: D.C. Heath \& Company.

Farrell, T.S.C. (2007). Reflective language teaching: From research to practice. London: Continuum Press.

Feza-Piyose, N. (2012). Language: A cultural capital for conceptualizing mathematics knowledge. International Electronic Journal of Mathematics Education, 7(2), 62-79.

Gulamhussein, A. (2013). Teaching the teachers: Effective professional development in an era of high stakes accountability. Alexandria, VA: Center for Public Education Available from http://www.centerforpubliceducation.org/teachingtheteachers

Hatch, J.A. (2002). Doing qualitative research in educational settings. Albany, NY: State University of New York Press.

Hawley, W., \& Valli, L. (1999). The essentials of effective professional development: A new consensus. In L. Darling-Hammond, \& G. Sykes (Eds.), Teaching as the learning profession: Handbook of policy and practice (pp. 127-150). San Francisco, CA: Jossey-Bass.

Hiebert, J., Carpenter, T.P., Fennema, E., Fuson, K., Wearne, D., Murray, $\mathrm{H}$, et al. (1997). Making sense: Teaching and learning mathematics with understanding. Portsmouth, $\mathrm{NH}$ : Heinemann.

Hiebert, J., \& Wearne, D. (1993). Instruction, understanding and skills in multidigit addition and subtraction. Cognition and Instruction, 14, 251-283. https://doi. org/10.1207/s1532690xci1403_1

Kadel, S. (1992). Problem-centred learning in mathematics and science. Hot topics: Usable research. Washington, DC: South Eastern Regional Vision for Education.

Kelly, A.E. (2003). Theme issue: The role of Design in educational research. Educationa Researcher, 32(1), 3-4. https://doi.org/10.3102/0013189X032001003

Krulik, S., \& Rudnick, J.A. (1980). Problem solving: A handbook for teachers. (2nd edn.). Boston, MA: Allyn and Bacon.

Loucks-Horsley, S., Hewson, P.W., Love, N., \& Stiles, K.E. (1998). Designing professiona development for teachers of Science and Mathematics. Thousand Oaks, CA: Corwin Press, Inc.

Loucks-Horsley, S., \& Stiegelbauer, S. (1991). Using knowledge of change to guide staff development. In A Lieberman, \& L. Miller (Eds.), Staff development for education in the 90s. New York, NY: Teachers College Press.

McKenney, S.E., \& Reeves, T.C. (2012). Conducting educational design research. New York, NY: Routledge.

McMillan, J.H., \& Schumacher, S. (2014). Research in education: Evidence-based inquiry. (7th edn.). Harlow: Pearson.

Mji, A., \& Makgato, M. (2006). Factors associated with high school learners' poor performance: A spotlight on mathematics and physical science. South African Journal of Education, 26(2), 253-266.

Ministry of Education Singapore. (2013). Mathematics syllabus. Secondary one to four. Express Course. Normal (Academic) Course). Curriculum Planning and Development Division. Available from http://www.moe.gov.sg/education/ syllabuses/sciences/files/ordinary-and-normal-academic-level-maths-2013.pdf

Mullis, I., Martin, M., Foy, P., \& Arora, A. (2012). TIMSS 2011 International results in mathematics. Chestnut Hill, MA: TIMSS \& PIRLS International Study Center and IEA. 
Murray, H., Olivier, A., \& Human, P. (1998). Learning through problem solving. In A. Olivier, \& K. Newstead (Eds.), Proceedings of the $22^{\text {nd }}$ International Conference
for the Psychology of Mathematics Education, (Vol. 1, pp 169-185). Stellenbosch: PME.

National Council of Teachers of Mathematics. (2000). Principles and standards for teaching school mathematics. Reston, VA: NCTM.

Opie, C. (2004). Doing educational research. London: Sage.

Polya, G. (1957). How to solve it: A new aspect of mathematical method. (2nd edn.). Princeton, NJ: Princeton University Press.

Putnam, R., \& Borko, H. (1997). Teacher learning: Implications of new views of cognition. In B.J. Biddle, T.L. Good, \& I.F. Goodson (Eds.), The international handbook of teachers and teaching (pp. 1223-1296). Dordrecht: Kluwer Academic handbook of
Publishers.

Quick, H., Holtzman, D., \& Chaney, K. (2009). Professional development and instructional practice: Conceptions and evidence of effectiveness. Journal of instructional practice: Conceptions and evidence of effectiveness. Journal of Education for Learners Placed
org/10.1080/10824660802715429

Schön, D.A. (1983). The reflective practitioner: How professionals think in action New York, NY: Basic Books.

Schunk, D.H. (2012). Learning theories: An educational perspective. Boston, MA: Pearson.

Setati, M., \& Barwell, R. (2006). Discursive practices in two multilingual mathematics classrooms: An international comparison. African Journal for Research in Mathematics, Science and Technology Education, 10(2), 27-38. https://doi.org/ 10.1080/10288457.2006.10740602

Slattery, P. (2013). Curriculum development in the postmodern era: Teaching and learning in an age of accountability. New York, NY: Routledge.

Taylor, N., \& Vinjevold, P. (1999). Getting learning right: Report of the President's Education Initiative Research Project. Johannesburg: Joint Education Trust.
Van den Akker, J. (1999). Principles and methods of development research. In J. van den Akker, N. Nieveen, R.M. Branch, K.L. Gustafson, \& T. Plomp (Eds.), Design methodology and developmental research in education and training (pp. 1-14). methodology and developmental research

Van den Akker, J., Gravemeijer, K., McKenney, S., \& Nieveen, N. (2006). Introducing education design research. In J. van den Akker, K. Gravemeijer, S. McKenney, \& N. Nieveen (Eds.), Educational design research (pp. 3-7). New York, NY: Routledge.

Van de Walle, J.A., Karp, K.S., \& Bay-Williams, J.M. (2013). Elementary and middle school mathematics: Teaching developmentally. (8th edn.). New York, NY: Pearson Education.

Villegas-Reimers, E. (2003). Teacher professional development: An international review of the literature. Paris: UNESCO International Institute for Educational Planning.

Vygotsky, L.S. (1986). Thought and language. Cambridge, MA: Massachusetts Institute of Technology.

Wang, F., \& Hannafin, M.J. (2005). Design-based research and technology-enhanced learning environments. Educational Technology Research and Development, 53(4), 5-23. https://doi.org/10.1007/bf02504682

Webb, L., \& Webb, P. (2008). Introducing discussion into multilingual mathematics classrooms: An issue of code switching. Pythagoras, 67, 26-32. https://doi. org/10.4102/pythagoras.v0i67.71

Wei, R.C., Darling-Hammond, L., Andree, A., Richardson, N., \& Orphanos, S. (2009). Professional learning in the learning profession: A status report on teacher development in the United States and abroad. Dallas, TX: National Staff Development Council.

Wessels, D.C.J., \& Kwari, R. (2003). The nature of problem solving in mathematics: Traditional vs contemporary views. Journal for Christian Scholarship, 39, 69-93.

Wilson, S.M., Shulman, L.S., \& Richert, A.E. (1987). '150 different ways' of knowing: Representations of knowledge in teaching. In J. Calderhead (Ed.), Exploring teachers' thinking (pp. 104-124). London: Cassell.

Woolfolk, A.N. (2007). Educational psychology. (10th edn.). Boston, MA: Allyn \& Bacon. 


\section{Appendix 1 \\ Observation Comment Card}

\begin{tabular}{|c|c|c|c|}
\hline Stage & What teacher should do & $\begin{array}{l}\text { What teacher really did } \\
\text { (evidence/indicators) }\end{array}$ & Comments \\
\hline Before & $\begin{array}{l}\text { - Give instructional strategies and activities that incorporate learners' prior knowledge. } \\
\text { - Pose the problem to learners orally or in a written form. } \\
\text { - Read or have a learner read the problem. } \\
\text { Make sure that learners understand the problem before they begin to work on it, for } \\
\text { example ask learners to identify what is asked for in the problem, discuss any unfamiliar } \\
\text { terms in the problem, or ask learners to paraphrase the problem in their own words. } \\
\text { - Brainstorm possible solution strategies. }\end{array}$ & & \\
\hline During & $\begin{array}{l}\text { - Move among learners. } \\
\text { - Listen prudently to learners' thoughts and discussions. } \\
\text { - Embrace the dynamics of group work. } \\
\text { - fuestion indingidual learners or groups about the strategy they are using and their } \\
\text { - Probe learners with suitable questions to assist them clarify the direction they are taking } \\
\text { in solving the problem. } \\
\text { - Provide hints to learners who require them. } \\
\text { - Persuade learners to seek and value alternative modes of problem-solving. } \\
\text { - Encourage learners to make extensions or generalisations. }\end{array}$ & & \\
\hline After & $\begin{array}{l}\text { - Encourage learners to reflect on their solutions and on the processes they used. } \\
\text { - Invite learners to justify their solutions. } \\
\text { - Engage the class in productive discourse by letting learners communicate their ideas in } \\
\text { words and diagrams, and allowing them to share their ideas and strategies. } \\
\text { - Probe the learners how the problem is similar to and different from problems they have } \\
\text { previously solved. } \\
\text { - Have learners discuss the critical aspects of the problem. } \\
\text { - Summarise the chief points of the discussion and establish that all learners comprehend } \\
\text { them. }\end{array}$ & & \\
\hline
\end{tabular}

\section{Appendix 2}

\section{Mathematical Problem-solving Skills Inventory (MPSSI)}

Date:

Name:

Grade:

Dear learner

Please fill in the table below, where $1=$ strongly disagree, $2=$ disagree, $3=$ neither agree nor disagree, $4=$ agree and $5=$ strongly agree

\begin{tabular}{lll}
\hline No. & Mathematical problem-solving skills inventory & $\mathbf{1}$ \\
\hline 1 & I always read the problem carefully to understand it & $\mathbf{3}$ \\
2 & I underline important words when doing a problem \\
3 & I draw pictures to understand a problem \\
5 & I imagine the problem I am doing in my head \\
6 & I can separate different parts of the problem \\
7 & I carefully plan how I will do a problem \\
8 & I remember other problems that I have solved before that look like the problem I am doing \\
9 & I can easily explain what I am doing when solving a problem \\
10 & I keep checking if the way I am solving the problem is correct \\
11 & If I get stuck, I go back to the problem to check if I understood it correctly \\
12 & I try and find different ways to solve a problem \\
13 & I look back at the way I solved a problem to see if it makes sense \\
\hline
\end{tabular}

